\title{
Konstruksi Vektor Biner Mengandung Gen Hibrid cryIB-cryIAa untuk Transformasi Agrobacterium Tanaman Padi (Oryza sativa L)
}

\author{
Construction of binary vectors carrying cryIB-cryIAa hybrid gene suitable for \\ Agrobacterium-mediated transformation in rice (Oryza sativa $\mathrm{L}$ )
}

\author{
Syamsidah Rahmawati dan Inez H. Slamet-Loedin
}

Pusat Penelitian Bioteknologi-LIPI, Jl. Raya Bogor KM 46 Cibinong 16911

\begin{abstract}
This study aimed to obtain binary vectors carrying cryIB-cryIAa hybrid gene suitable for Agrobacterium-mediated transformation of two Indonesian rice cultivars, Rajalele (Javanica) and Cisadane (Indica). Introduction of hybrid Bt toxin, encoded by cryIBcryIAa hybrid gene with different binding receptor in the insect gut driven by maize ubiquitin promoter, was intended to reduce the possibility of the appearance of stem borer resistant to Bt toxin. A HindIII fragment containing the ubi cryIB-cryIAa hybrid gene was excised from pBKS ubi cryIB-cryIAa and cloned into the HindIII site of binary vector pCAMBIA 1301, 1303, or 1304. Restriction analysis of recombinant plasmids confirmed the insertion of the gene and demonstrated that the gene inserted in two orientations. The recombinant plasmids were transformed into electrocompetent Agrobacterium tumefaciens EHA105 by electroporation. Embryogenic calli of Rajalele and Cisadane were co-cultivated with A. tumefaciens EHA 105 harbouring binary vector pCAMBIA 1301, 1303, or 1304 containing ubi cryIB-cryIAa. GUS histochemical assay revealed that high transformation efficiency $(\mathbf{7 5 - 1 0 0 \% )}$ on both cultivars were obtained from embryogenic calli transformed with pCAMBIA 1303 or 1304.
\end{abstract}

Key words: cryIB-cryIAa hybrid gene, binding site, Agrobacterium transformation, Oryza sativa

Diterima: 6 Mei 2003, disetujui: 17 Juni 2003

\section{Pendahuluan}

Penggerek batang kuning (Scirpophaga incertulas) merupakan hama utama tanaman padi di Indonesia setelah tikus dan wereng coklat (Nilaparvata lugens), yang mengakibatkan penurunan produksi padi ratarata $13 \%$ dan pada puncak ledakan hama dapat mencapai $25 \%$ dari total produksi padi di Indonesia (BPS, 1996).

Penggunaan varitas unggul tahan hama adalah salah satu upaya pengendalian hama yang ramah lingkungan. Namun demikian, sumber gen menjadi salah satu faktor pembatas pada pemuliaan konvensional. Untuk meningkatkan keanekaragaman genetik padi yang mempunyai sifat tahan terhadap penggerek batang perlu aplikasi teknologi DNA rekombinan. Salah satu keuntungan penggunaan teknologi DNA adalah bahwa introduksi gen dapat dilakukan pada spesies yang tidak berkerabat.

Introduksi gen cry dari bakteri tanah Bacillus thuringiensis yang menyandikan protein atau toksin BT telah berhasil dilakukan pada berbagai kultivar tanaman padi, sehingga tanaman padi mempunyai kemampuan internal untuk mengendalikan serangga hama. Gen cryIA(b) atau cryIA(c) yang diekspresikan pada padi, misalnya, sangat efektif dalam mengendalikan serangan larva serangga penggerek batang kuning (Scirpophaga 
incertulas), (Alam et al., 1998; Ghareyazie et al., 1997; Nayak et al., 1997). Gen cryIB di bawah kontrol promoter ubiquitin pada jagung dilaporkan sangat efektif mengendalikan penggerek batang kuning dan bergaris (Chilo suppressalis) (Breitler, et al., 2000).

Namun, seperti halnya tanaman hasil pemuliaan konvensional, ketahanan tanaman transgenik dapat dipatahkan. Cohen (2000) seorang ahli entomologi di IRRI (International Rice Reseach Institute) menyarankan untuk hanya menanam tanaman transgenik yang mengandung high dose toxin bersama dengan tanaman non-transgenik (refugee), atau menanam tanaman mengandung lebih dari satu gen ketahanan yang mempunyai binding site yang berbeda di dalam pencernaan larva serangga. Alcantara et al. (2000) melaporkan bahwa beberapa toxin cry mempunyai binding site yang berbeda di dalam pencernaan larva serangga dua spesies penggerek batang, Chilo suppressalis dan Scirpophaga incertulas. Selanjutnya mereka menyarankan untuk mengkombinasikan penggunaan toxin cry yang berbeda binding site ini untuk memperoleh tanaman transgenik yang memiliki resistensi dalam jangka waktu yang lama. Misalnya kombinasi gen cryIA(b) atau cryIA(c) dengan gen cry $1 \mathrm{C}$, cry $2 \mathrm{~A}$, atau cry $9 \mathrm{C}$. Penemuan ini sangat menguntungkan dalam mengembangkan strategi untuk memperlambat laju pematahan ketahanan oleh serangga, karena kemungkinan mutasi dua reseptor yang berbeda pada serangga lebih kecil.

Pada penelitian ini fusi dua gen cryIBcryIAa dengan binding site berbeda di bawah kendali promoter "constitutive" ubiquitin diintroduksi ke dalam genom padi menggunakan transformasi Agrobacterium. Pada tahap pertama penelitian, gen ubi cryIBcryIAa disubklon ke dalam beberapa seri vektor biner pCAMBIA. Tujuannya adalah untuk menyediakan plasmid biner mengandung gen cryIB-cryIAa dan membandingkan efisiensi transformasi tiga plasmid untuk transformasi Agrobacterium. Di dalam tulisan ini dilaporkan bahwa gen cryIB-cryIAa telah berhasil disubklon ke dalam vektor biner dan dapat digunakan untuk mentransformasi padi kultivar Rajalele (Javanica) dan Cisadane (Indica).

\section{Metode Penelitian}

\section{Subkloning}

Plasmid pBKS ubi cryIB-cryIAa dipotong dengan enzim restriksi HindIII, kemudian diligasi dengan plasmid biner pCAMBIA 1301, 1303, dan 1304 yang telah dipotong dengan HindIII. Plasmid pBKS membawa gen ketahanan terhadap ampisilin sedangkan plasmid pCAMBIA mengandung gen penyeleksi ketahanan terhadap kanamisin (nptII) untuk seleksi di E. coli. Plasmid pCAMBIA mempunyai gen penseleksi $(h p t)$ dan gen pelapor ( $g u s$ atau gus;gfp) di bawah kendali promoter CaMV35S di dalam TDNAnya. DNA hasil ligasi ditransformasi ke dalam sel kompeten Escherichia coli XL-1 menggunakan metode heat shock. Koloni putih E. coli XL-1 yang diduga mengandung plasmid rekombinan ditumbuhkan pada media padat LB (Luria Bertani) yang mengandung tetrasiklin $(10 \mathrm{mg} / \mathrm{l})$ dan kanamisin $(50 \mathrm{mg} / \mathrm{l})$ atau LB yang mengandung tetrasiklin (10 $\mathrm{mg} / \mathrm{l})$ dan ampisilin $(50 \mathrm{mg} / \mathrm{l})$. Koloni putih yang mengandung pCAMBIA yang telah disisipi gen target hanya tumbuh pada media yang mengandung kanamisin $(50 \mathrm{mg} / \mathrm{l})$ tidak pada media yang mengandung ampisilin (50 $\mathrm{mg} / \mathrm{l})$ (Gambar 2). Konfirmasi penyisipan gen ubi cryIB-cryIAa dilakukan dengan memotong plasmid rekombinan dengan enzim $B g l I I$. Fragmen DNA hasil restriksi dipisahkan pada gel agarose $(1 \%)$ dengan elektroforesis. Ada dua kemungkinan orientasi penyisipan DNA, yang masing-masing akan menghasilkan empat pita. Pada orientasi I (arah ekspresi dari kiri ke kanan) akan muncul pita dengan ukuran 13 314, 3 868, 1 349, dan 779 bp, sedangkan pada orientasi II (arah ekspresi dari kanan ke kiri) akan terlihat pita DNA dengan ukuran 11 602, 3 868, 1 722, dan 1349 bp.

\section{Transformasi plasmid biner ke dalam Agrobacterium}

Plasmid rekombinan ditransformasikan ke dalam sel elektrokompeten Agrobacterium tumefaciens EHA105 menggunakan teknik elektroporasi (Bio-rad) dan ditumbuhkan pada media LB yang mengandung antibiotik 
rifampicin $20 \mathrm{mg} / \mathrm{l}$ dan kanamisin $50 \mathrm{mg} / \mathrm{l}$. Beberapa koloni yang tumbuh dipindahkan ke media cair dan diinkubasi selama dua hari $\left(28^{\circ} \mathrm{C}\right)$ untuk diperbanyak dan DNA plasmid diisolasi dengan metode lisis alkalin (Sambrook et.al., 1989). Plasmid DNA dipotong dengan enzim restriksi XhoI untuk konfirmasi. Pemotongan DNA plasmid diharapkan akan menghasilkan pita DNA dengan ukuran 13 135, 1 788, 1 726, 1 094, dan 798 bp, pada orientasi I, dan 10 893, 4 030, 1 726, 1 094, dan 798 bp pada orientasi II.

\section{Induksi kalus}

Kalus embriogenik diinisiasi dari benih padi (Oryza sativa L.) kultivar Rajalele dan Cisadane. Benih dikupas, disterilisasi dengan etanol $70 \%$ selama 1 menit, kemudian direndam dalam benlate $3 \%$ dan dalam larutan bayclin $70 \%$ ( $\mathrm{NaClO} \mathrm{5,25 \% ),} \mathrm{masing-masing}$ selama 30 menit. Benih dicuci dengan air steril sebanyak lima kali 10 menit dengan pengocokan sebelum dikultur pada media IK3 (Slamet-Loedin, 1997). Benih ditanam selama 1 minggu pada kondisi gelap. Kalus dari bagian skutelum embrio diisolasi dan dipindahkan pada media IK3 baru, kemudian dilanjutkan dengan menanam kalus pada kondisi gelap selama 2 minggu. Kalus diamati di bawah mikroskop, selanjutnya kalus embriogenik dikecilkan dan dipindahkan ke media IK3 baru dan diinkubasi selama 4 hari sebelum di ko-kultivasi.

\section{Transformasi Agrobacterium}

Koloni tunggal Agrobacterium EHA105 (pCAMBIA 1301, 1303 atau 1304 ubi cryIBcryIAa) ditumbuhkan pada media padat LB yang mengandung antibiotik rifampisin 20 (mg/l) dan kanamisin (50 mg/l), diinkubasi pada suhu $28^{\circ} \mathrm{C}$ selama tiga hari. Kalus embriogenik umur 2 minggu yang telah dikecilkan 4 hari sebelum infeksi direndam dalam suspensi sel Agrobacterium $\left(\mathrm{OD}_{600}=\right.$ 0,3-0,4) yang mengandung $0,1 \mathrm{mM}$ asetosiringon selama 30 menit, dikeringkan pada kertas saring steril dan diko-kultur selama tiga hari pada media IK3 yang mengandung $100 \mathrm{mM}$ asetosiringon pada kondisi gelap (18$22^{\circ} \mathrm{C}$ ). Kalus kemudian dicuci dengan larutan cefotaxime $(400 \mathrm{mg} / \mathrm{l})$ dan dipindahkan ke media IK3 yang mengandung cefotaxime 250 $\mathrm{mg} / \mathrm{l}$ dan higromisin $50 \mathrm{mg} / \mathrm{l}$.

\section{Uji gen gus}

Ekspresi transient gen gus diuji secara histokimia 3 hari setelah infeksi mengikuti metode Jefferson (1987). Delapan kalus digunakan pada setiap perlakuan. Kalus diinkubasi selama satu malam pada suhu $37^{\circ} \mathrm{C}$. Kalus dicuci dengan etanol $70 \%$ sebelum penghitungan jumlah kalus berwarna biru dilakukan. Spot biru diamati di bawah mikroskop (Olympus-SZPT) dan kalus yang mempunyai spot biru adalah kalus yang mengekpresikan $\beta$-glucuronidase.

\section{Hasil dan Pembahasan}

\section{Subkloning}

Introduksi fusi dua gen cryIB-cryIAa yang berbeda binding site dilakukan sebagai salah satu pendekatan untuk memperlama ketahanan tanaman padi transgenik terhadap penggerek batang, karena kemungkinan terjadinya mutasi pada dua gen lebih kecil dibandingkan dengan satu gen. Penyisipan fusi gen tersebut ke dalam vektor biner merupakan salah satu syarat yang harus dipenuhi untuk keberhasilan transformasi Agrobacterium. Penyisipan gen hybrid cryIB-cryIAa dengan binding site berbeda di bawah kendali promotor constitutive ubiquitin dari jagung ke dalam vektor biner ditujukan untuk menyediakan vektor biner mengandung gen hibrid cryIB-cryIAa yang cocok untuk transformasi Agrobacterium. Penyisipan gen target ke dalam vektor biner pCAMBIA dengan cara yang sederhana dan singkat, yaitu dengan memotong plasmid pBKS ubi cryIBcryIAa dengan enzim restriksi HindIII dipurifikasi dan langsung diligasi dengan plasmid pCAMBIA yang telah dipotong dengan HindIII tanpa harus memisahkan terlebih dahulu plasmid pBKS dengan gen ubi cryIB-cryIAa. DNA hasil ligasi kemudian ditransformasikan ke dalam sel kompeten E.coli. Seleksi dilakukan dua tahap, pertama seleksi biru putih. Koloni yang berwarna biru 
adalah koloni yang mengandung plasmid (pBKS atau pCAMBIA) yang tersambung kembali tanpa ada sisipan DNA lain (self ligation). Sebaliknya koloni putih terdiri dari sel yang mengandung DNA sisipan. Tahap kedua adalah seleksi dengan menumbuhkan koloni putih pada dua media seleksi, yaitu LB mengandung tetrasiklin $(10 \mathrm{mg} / \mathrm{l})$ dan ampisilin $(50 \mathrm{mg} / \mathrm{l})$, dan LB mengandung tetrasiklin (10 $\mathrm{mg} / \mathrm{l})$ dan kanamisin $(50 \mathrm{mg} / \mathrm{l})$. Koloni yang diinginkan adalah koloni putih yang hanya tumbuh pada media LB mengandung tetrasiklin $(10 \mathrm{mg} / \mathrm{l})$ dan kanamisin $(50 \mathrm{mg} / \mathrm{l})$ (Gambar 1).

Berdasarkan hasil uji restriksi yang dilakukan terhadap DNA plasmid rekombinan yang diisolasi dari koloni putih E. coli tahan kanamisin $(50 \mathrm{mg} / \mathrm{l})$, diperoleh dua pola, masing-masing dengan empat pita DNA seperti yang diharapkan. Pola pertama, dihasilkan pita masing-masing dengan ukuran 13 314, 3 868, 1 349, dan 779 bp menunjukkan potongan DNA dengan orientasi I (arah ekspresi dari kiri ke kanan), sedangkan pola kedua terlihat pita DNA dengan ukuran 11 602, 3 868, 1 722, dan 1349 bp yang menunjukkan potongan DNA dengan orientasi II (arah ekspresi dari kanan ke kiri) (Gambar 2a dan 2b).

\section{Transformasi Agrobacterium}

Plasmid rekombinan yang sudah terbukti mengandung gen hibrid cryIB-cryIAa di bawah kendali promoter ubiquitin ditransformasikan ke dalam sel Agrobacterium tumefaciens EHA105 dengan metode elektroporasi. Konfirmasi hasil transformasi dilakukan dengan memotong DNA plasmid yang diisolasi dari Agrobacterium dengan enzim restriksi XhoI. Gambar 2c dan 2d menunjukkan bahwa DNA yang dipotong dengan enzim $\mathrm{XHoI}$ menghasilkan pola pita DNA yang diharapkan, yaitu pita DNA dengan ukuran 13 135, 1 788, 1 726, 1 094, dan 798 bp, pada orientasi I, dan 10 893, 4 030, 1 726, 1 094, dan 798 bp pada orientasi II. Gambar 4 menunjukkan orientasi penyisipan gen target di dalam T-DNA Hasil pemotongan plasmid DNA mempertegas bahwa Agrobacterium mengandung plasmid yang diharapkan.

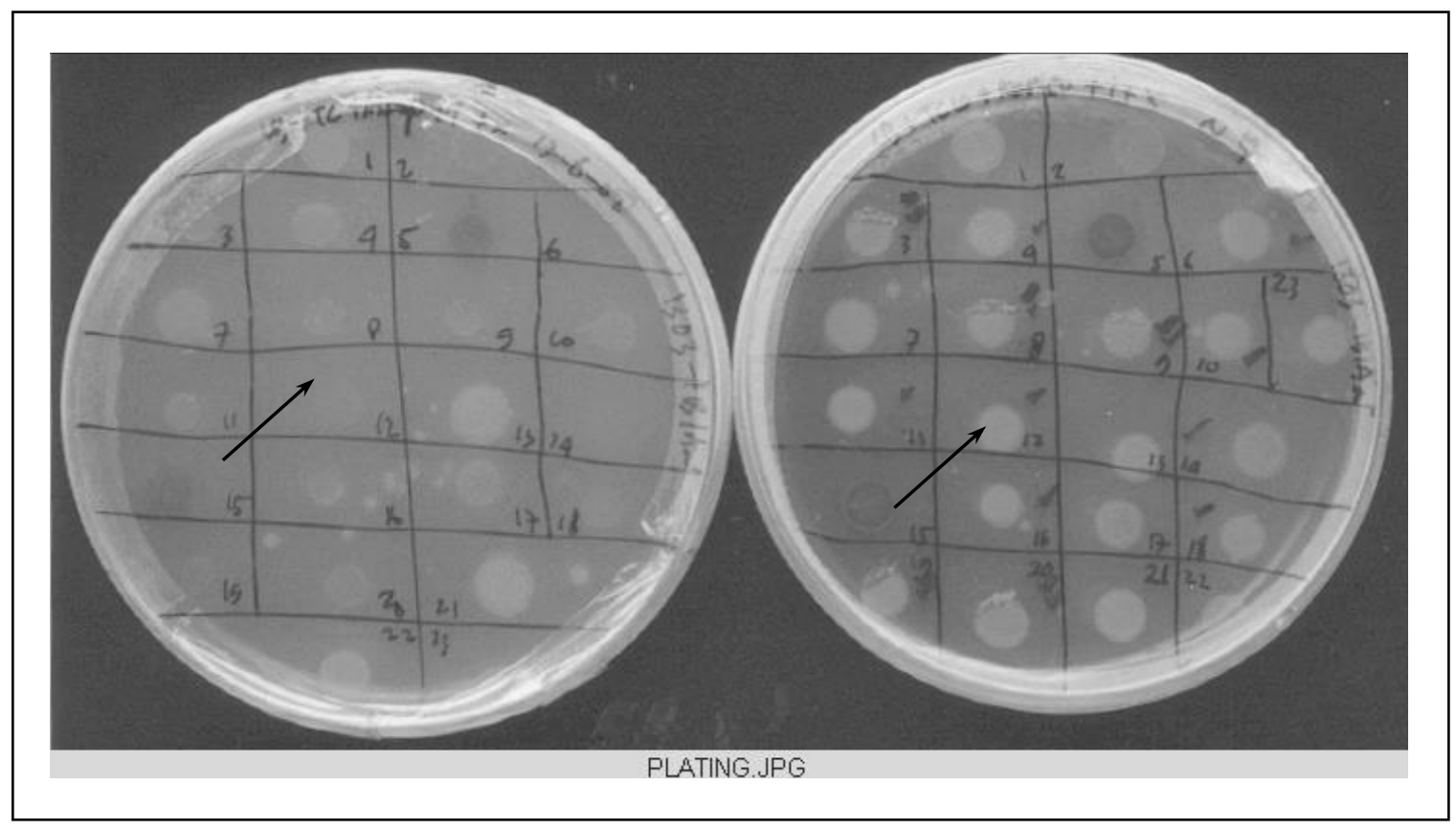

Gambar 1. Seleksi sel E. coli. Tanda panah menunjukkan koloni putih (pCAMBIA ubi cryIB-cryIAa) yang tidak tumbuh pada media LB+amp (kiri), tumbuh pada media LB+kan (kanan). 


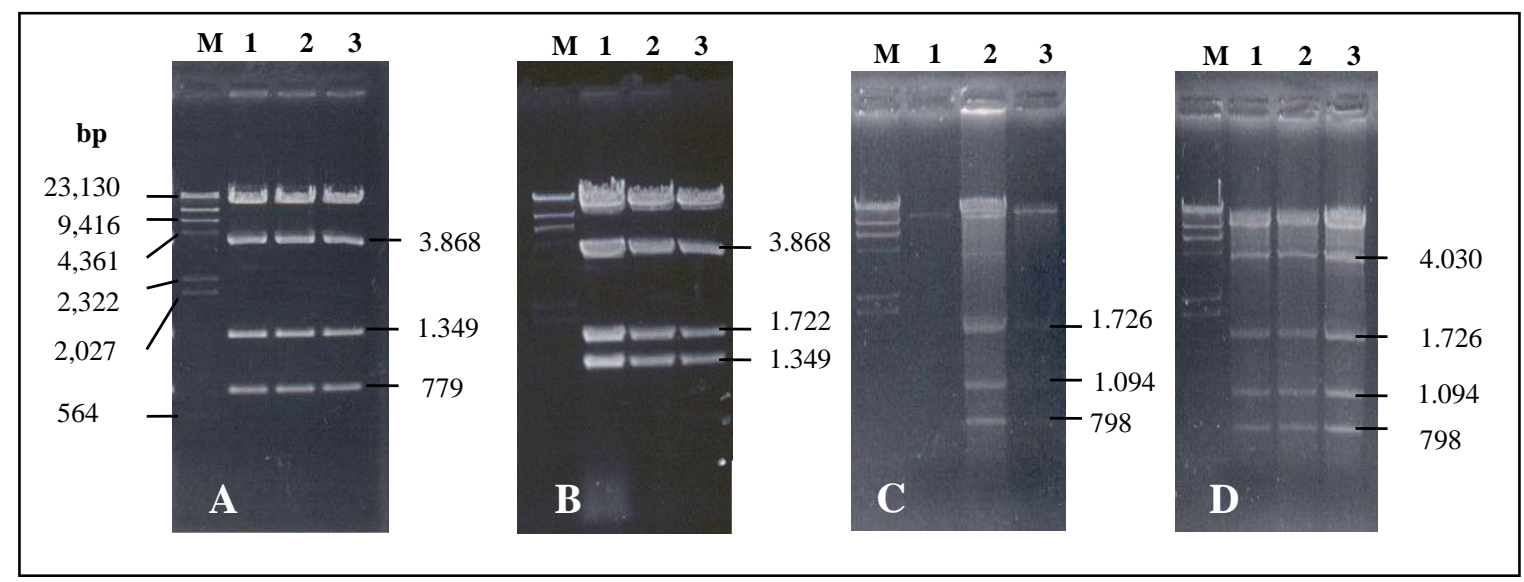

Gambar 2. Hasil pemotongan DNA plasmid rekombinan mengandung gen UBI cryIB-cryIAa, yang diisolasi dari E. Coli dengan enzim restriksi BglII (A dan B), dan dari Agrobacterium dengan enzim restriksi Xhol (C dan D). A dan C: Peta (orientasi) I; B dan D: Peta II. M: Marker DNA $\lambda$-Hind-III, I. PCAMBIA 1301 UBI-cryIB-cryIAa, 2 pCAMBIA 1303 UBI-cryIBcryIAa, dan 3. pCAMBIA 1304 UBI-cryIB-cryIAa.

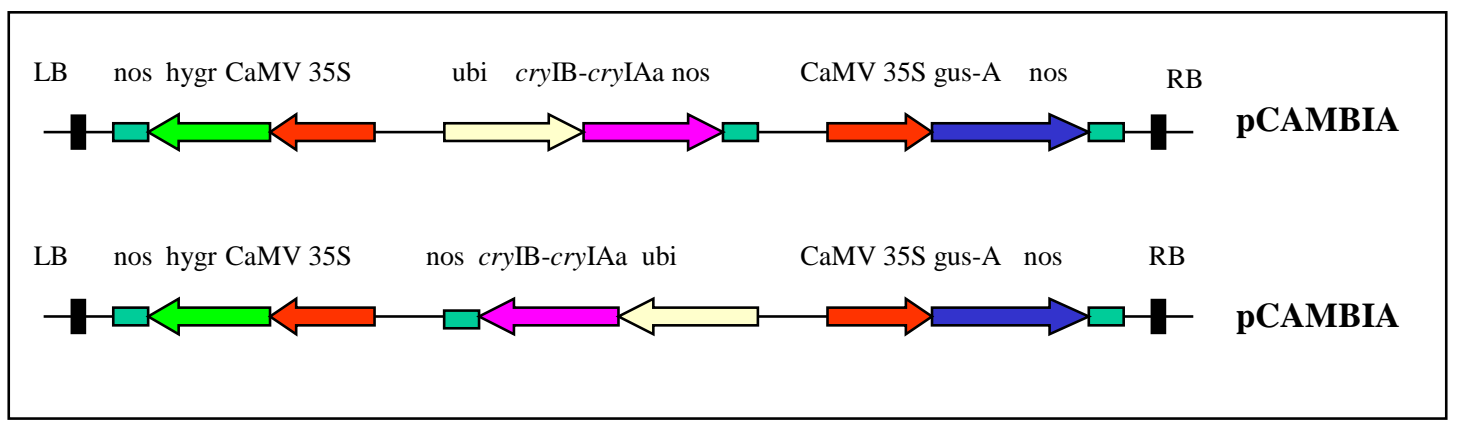

Gambar 3. Orientasi penyisipan gen hybrid ubi cryIB-cryIAa pada daerah T-DNA. Orientasi I arah ekspresi dari kiri ke kanan (atas), dan orientasi II arah ekspresi dari kanan ke kiri (bawah)

\section{Efisiensi transformasi pada kalus embriogenik dua kultivar tanaman padi}

Agrobacterium yang telah terbukti mengandung plasmid rekombinan (pCAMBIA 1301 ubi cryIB-cryIAa, pCAMBIA 1303 ubi cryIB-cryIAa, dan pCAMBIA 1304 ubi cryIBcryIAa) selanjutnya digunakan untuk transformasi kalus embriogenik padi kultivar Rajalele dan Cisadane umur 2 minggu. Efisiensi transformasi dari ketiga seri plasmid pCAMBIA tersebut dibandingkan. Efisiensi transformasi dinilai berdasarkan perbandingan antara jumlah kalus yang mengekspresikan $\beta$-glucuronidase dengan jumlah kalus yang diuji. Uji ekspresi transient dari gen gus yang dilakukan tiga hari setelah infeksi menunjukkan bahwa padi kultivar Rajalele dan Cisadane mengekspresikan $\beta$-glucuronidase. Namun pola pewarnaan histokimia yang diberikan oleh masing-masing plasmid berbeda. Plasmid pCAMBIA 1303 dan 1304 memberikan jumlah kalus biru yang terbanyak (75-100\%) dengan warna yang biru merata, sedangkan pCAMBIA 1301 hanya memberikan warna spot biru yang dapat diamati di bawah mikroskop (Gambar 4). Meskipun frekuensi ekspresi transien yang tinggi tidak selalu menghasilkan frekuensi 
ekspresi stabil yang tinggi, hasil deteksi ekspresi gen gus pada 3 hari setelah kokultivasi dengan Agrobacterium (pCAMBIA UBI cryIB-cryIAa) menunjukkan bahwa vektor pCAMBIA 1303 dan 1304 lebih baik dibandingkan dengan pCAMBIA 1301. Oleh karena itu masih perlu pengujian untuk melihat kestabilan ekspresi gen asing tersebut pada tanaman padi pada generasi berikutnya.
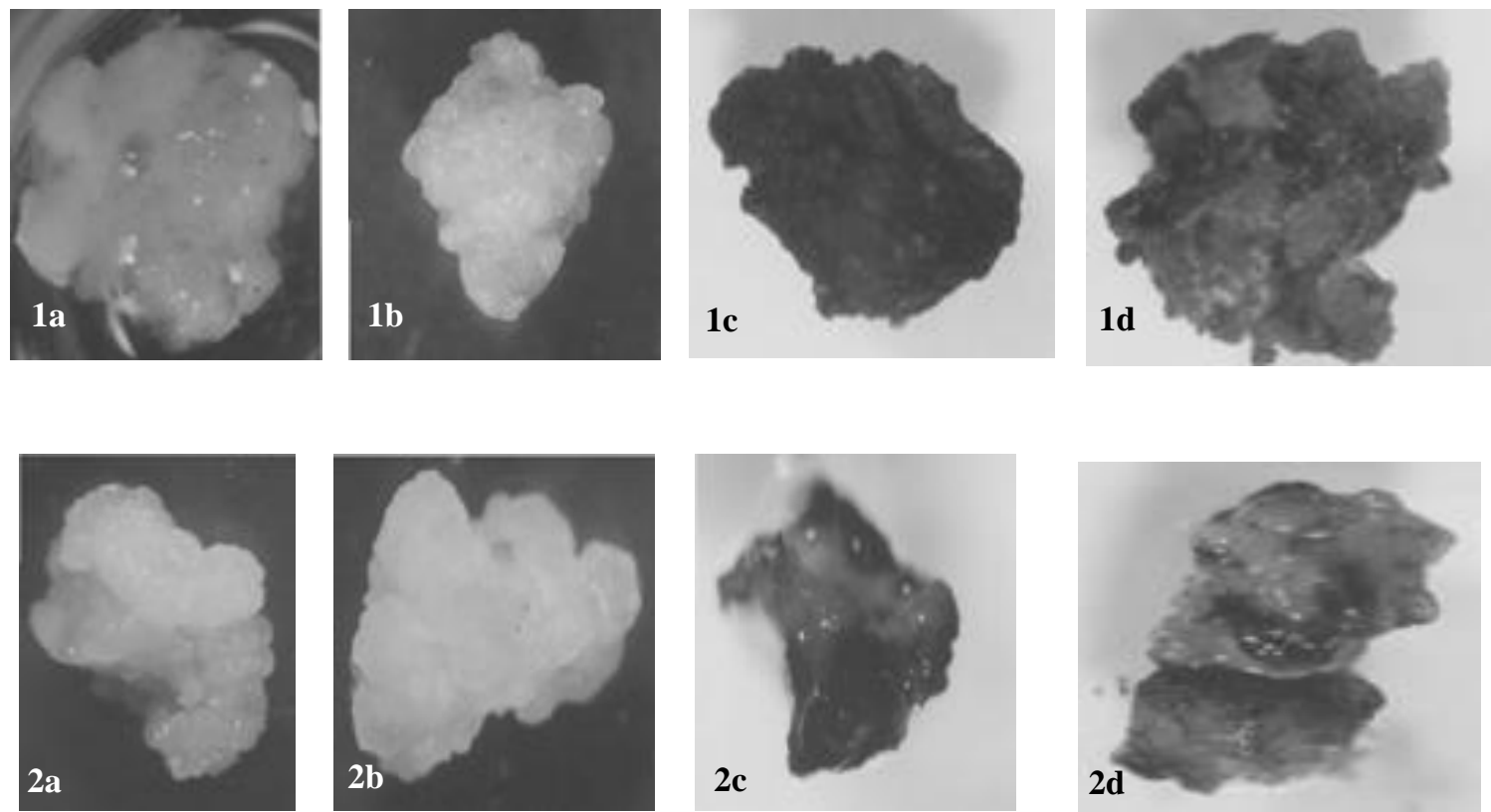

Gambar 4. Hasil uji GUS asai pada kalus padi kultivar Cisadane (atas) dan Rajalele (bawah). 1a, 2a ; kalus yang tidak ditransformasi. 1b, 2b: Spot biru ( tanda panah) pada kalus yang ditransformasi dengan pCAMBIA 1301 UBI cryIB-cryIAa. 1c, 2c: kalus yang ditransformasi dengan pCAMBIA 1303 UBI cryIB-cryIAa dan 1d, 2d: kalus yang ditransformasi dengan pCAMBIA 1304 UBI cryIBcryIAa

\section{Kesimpulan dan Saran}

Dari uraian di atas dapat disimpulkan bahwa vektor biner yang mengandung gen hibrid cryIB-cryIAa dengan binding site berbeda sudah diperoleh dan dapat digunakan untuk transformasi Agrobacterium dengan efisiensi tinggi berdasarkan uji gus pada tanaman padi baik kultivar Rajalele (Javanica) dan Cisadane (Indica).

\section{Ucapan Terima Kasih}

Ucapan terimakasih disampaikan kepada sdr Neneng Heryati, S.Si atas bantuan teknis yang diberikan selama kegiatan penelitian ini berlangsung. Penelitian ini didanai oleh Riset Unggulan Terpadu (RUT) IX No. kontrak 097.63/SK/RUT/2002, tanggal 29 Januari 2002 dan DIP tahun Anggaran 2002. Ucapan terimakasih disampaikan kepada Dr. E. Guiderdoni dari CIRAD, France atas pemberian fusi gen cryIB-cryIAa. 


\section{Daftar Pustaka}

Alam MF, Datta K, Abrigo E, Vasquez A, Senadhira D, Datta SK, 1998. Production of transgenic deepwater indica rice plants expressing a synthetic Bacillus thuringiensis cryIAb, gene with enhanced resistance to yellow stem borer. Plant Science 135: 25-30.

Alcantra EP, Aguda R, Dean DH, Cohen MB, 2000. Investigation of Bacillus thuringiensis $\delta$-endotoxin binding to midgut receptors of rice stem borers. International Rice Genetics Symposium. IRRI. 221.

Biro Pusat Statistik, 1996. Luas dan intensitas serangan organisme pengganggu tanaman dan bencana alam padi, palawija dan sayuran di Jawa. Biro Pusat Statistik. Jakarta.

Breitler, J. C., V. Marva, M. Royer, D. Meynard, J. M. Vassal, B. Vercambre, R. Frutos, J. Messeguer, R. Gabbarra \& E. Guerdoni. 2000. Ekspression of a Bacillus thuringiensis cryIB sintetic gen protects Mediterranen rice against the stripped stem borer. Plant Cell Report 19: 1995-1202.

Cohen, M,B., 2000. Bt rice: practical steps to sustainable use. International Rice Research Notes 25 (2):4-10.
Ghareyazie B, Alina F, Menguito CA, Rubia LG, de Palma JM, Liwanag EA, Cohen MB, Khush GS, Bennet J., 1997. Enhanced resistance to two stem borer in an aromatic rice containing a synthetic cry IA(b) gene. Molecular Breeding 3: 401-414.

Jefferson, RA., 1987. Assaying chimeric genes in plants: the GUS gene system. Plant Mol. Biol. Rep. 5: 387-405.

Nayak P, Basu D, Das S, Basu A, Ghosh D, Ramakhrisnan NA, Ghosh M, Sen SK,. 1997. Transgenic elite indica rice plants expressing cry Iac $\delta$-endotoxin of Bacillus thuringiensis are resistant against yellow stem borer (Scirpophaga incertulas). Proc. Natl. Acad Sci. USA Vol 94: 211-216.

Sambrook J, Fritsch E.F, Maniatis T., 1989. Molecular cloning: a laboratory manual $\left(2^{\text {nd }}\right.$ edition). Cold Spring Harbor Laboratory Press. USA.

Slamet-Loedin IH, Rahayu W, Sasongko BWP, Deswina P. (1997) Transformation of Indica and Javanica rice varieties mediated by Agrobacterium tumefaciens containing a versatile binary vector. Proceedings of The Indonesian Biotechnology Conference. 179188. 